\title{
REAKSI PASAR MODAL INDONESIA TERHADAP KESEPAKATAN INVESTASI ANTARA PEMERINTAH INDONESIA DENGAN PEMERINTAH ARAB SAUDI
}

\author{
Kartika Wijaya $^{1)}$, Hendra Gunawan ${ }^{2}{ }^{*}$ \\ ${ }^{1)}$ Administrasi Bisnis Terapan, Politeknik Negeri Batam \\ Batam, Indonesia \\ kartikawijaya.34@gmail.com \\ ${ }^{2)}$ Manajemen Bisnis, Politeknik Negeri Batam \\ Batam, Indonesia \\ hendra@polibatam.ac.id
}

\begin{abstract}
This research is an event study which aims to analyze the difference of abnormal return and trading volume activity of whole Indonesian Stock Exchange stocks before and after a political event occurring in the country. The object of observation was the announcement of the investment agreement between the Indonesian government and the Saudi Arabian government on March 01, 2017 using indicators of abnormal return and trading volume activity. Population and sample in this research are all the companies listed in Indonesian Stock Exchange, which are 539 companies. The data used are secondary data of daily closing stock price, IDX composite, daily trading volume and the number of outstanding stocks starting from February 01 to March 29, 2017. The statistical test used to test the hypothesis is paired sample t-test. The results showed that: (1). The investment agreement between the Indonesian government and the Saudi Arabian government has a positive insignificant effect on abnormal return of all IDX stocks simultaneously for the observation period days of 12th, 11th, 09th and 01st. (2). The investment agreement between the Indonesian government and the Saudi Arabian government also has a positive insignificant effect on trading volume activity of all IDX stocks simultaneously for the observation period days of 19th, 18th and 12th.
\end{abstract}

Keywords: abnormal return, event study, stock market, trading volume activity.

\begin{abstract}
Abstrak
Penelitian ini merupakan studi peristiwa yang bertujuan untuk menganalisis perbedaan abnormal return dan trading volume activity saham-saham BEI secara keseluruhan sebelum dan setelah peristiwa politik yang terjadi di dalam negeri. Peristiwa yang menjadi objek pengamatan adalah pengumuman kesepakatan investasi antara pemerintah Indonesia dengan pemerintah Arab Saudi pada tanggal 01 Maret 2017 dengan menggunakan indikator abnormal return dan trading volume activity. Populasi dan sampel dalam penelitian ini adalah seluruh perusahaan yang terdaftar di BEI, yaitu 539 perusahaan. Data yang digunakan adalah data sekunder berupa harga saham penutupan harian, Indeks Harga Saham Gabungan (IHSG), volume perdagangan harian dan jumlah saham yang beredar mulai dari tanggal 01 Februari sampai dengan 29 Maret 2017. Uji statistik yang digunakan untuk menguji hipotesis adalah paired sample t-test. Hasil penelitian menunjukkan bahwa: (1). Kesepakatan investasi antara pemerintah Indonesia dengan pemerintah Arab Saudi berpengaruh positif tidak signifikan terhadap abnormal return keseluruhan saham BEI secara bersamaan untuk periode pengamatan hari ke 12, 11, 09 dan 01. (2). Kesepakatan investasi antara pemerintah Indonesia dengan pemerintah Arab Saudi juga berpengaruh positif tidak signifikan terhadap trading volume activity keseluruhan saham BEI secara bersamaan untuk periode pengamatan hari ke 19, 18 dan 12.
\end{abstract}

Kata kunci: abnormal return, pasar saham, studi peristiwa, trading volume activity. 


\section{PENDAHULUAN}

Pasar modal merupakan tempat berlangsungnya kegiatan menjual dan membeli instrumen keuangan jangka panjang yang diterbitkan oleh pemerintah, public authorities ataupun perusahaan swasta (Luhur, 2010). Pasar modal sangat penting bagi pertumbuhan ekonomi suatu negara karena berfungsi sebagai sarana bagi masyarakat untuk berinvestasi dan sebagai sarana bagi perusahaan untuk mendapatkan dana dari investor.

Pasar modal dipengaruhi oleh berbagai macam perubahan-perubahan yang terjadi setiap hari, khususnya peristiwa atau sebuah pengumuman yang memiliki kandungan informasi penting bagi investor. Peristiwa dan pengumuman penting tersebut dapat dilihat dari segi ekonomi maupun non-ekonomi. Perubahan dan peristiwa yang terjadi selalu dicermati oleh pelaku pasar. Hal ini menjadi faktor pemicunya fluktuasi harga saham dan mempengaruhi volume perdagangan bursa efek di seluruh dunia.

Kondisi sosial, ekonomi dan juga politik di suatu negara dapat dipengaruhi oleh peristiwa dari dalam maupun luar negeri. Terlebih negara yang mempengaruhi peristiwa tersebut merupakan negara yang memiliki peran penting dalam aspek kegiatan ekonomi. Hubungannya dengan pasar modal, peristiwa penting dari dalam dan luar negeri mempengaruhi perilaku pasar dalam mengambil keputusan investasi. Pelaku pasar selalu memastikan apakah peristiwa tersebut berdampak negatif atau positif terhadap bursa efek.

Raja Arab Saudi, Salman bin Abdulaziz Al Saud berkunjung ke Indonesia untuk melakukan pertemuan bilateral dengan Presiden Joko Widodo di Istana Bogor, Jawa Barat (nasional.kompas.com, 04 Februari 2018). Kunjungan Raja Salman terbagi menjadi dua agenda, pada tanggal 01-03 Maret 2017 Raja Salman berada di Jakarta. Selanjutnya pada tanggal 04-09 Maret 2017 Raja Salman berlibur di Bali.

Hari pertama kunjungan Raja Salman ke Indonesia berjalan lancar. Pertemuan bilateral yang berlangsung produktif dan sukses tersebut menghasilkan beberapa kesepakatan. Tercatat ada 11 kesepakatan yang berhasil dicapai oleh pemerintah Indonesia dengan pemerintah Arab Saudi. 11 kesepakatan dituangkan ke dalam bentuk nota kesepahaman. Kesepakatan tersebut mencakup peningkatan hubungan antar kedua negara dalam bidang kesehatan, kebudayaan, transportasi, kerja sama luar negeri, aeronautika, pendidikan, keagamaan serta perdagangan (news.detik.com, 04 Februari 2018).

Presiden Joko Widodo menyepakati kerjasama dengan Raja Salman senilai Rp93 triliun dalam pertemuan bilateral di Istana Bogor lalu. Kerja sama dengan nilai investasi terbesar jatuh kepada perusahaan minyak Arab Saudi yakni Aramco, senilai US\$6 miliar atau Rp8 triliun. Selain itu Indonesia juga menerima bantuan dana US\$1 miliar atau Rp13 triliun dari Saudi Fund Development untuk pembangunan infrastruktur, air minum dan perumahan (bbc.com, 04 Februari 2018).

Berdasarkan fenomena keputusan investasi Raja Salman di Indonesia tersebut dapat dicermati jika kemungkinan pasar modal akan bereaksi dan mempengaruhi perekonomian negara. Studi kasus (event study) digunakan untuk menguji efisiensi pasar dan kandungan informasi dari sebuah pengumuman. Jika sebuah pengumuman mengandung informasi, hal tersebut akan ditunjukkan dengan adanya perubahan harga dari sekuritas yang bersangkutan. Reaksi pasar modal dapat diukur menggunakan return atau dengan menggunakan abnormal return sebagai nilai perubahan harga. Sebaliknya, jika sebuah pengumuman tidak mengandung informasi, maka tidak akan memberikan abnormal return kepada pasar (Jogiyanto, 2010:7). 
Kartika Wijaya \& Hendra Gunawan, Reaksi Pasar Modal Indonesia Terhadap...

Selain menggunakan return, reaksi pasar modal juga dapat diukur melalui parameter pergerakan trading volume activity. Analisis trading volume activity dilakukan untuk dapat melihat reaksi pasar modal terhadap sebuah informasi melalui pergerakan-pergerakan aktivitas volume perdagangan saham dan juga untuk memperoleh gambaran yang jauh lebih komprehensif mengenai reaksi pasar.

Bagi pelaku pasar modal, informasi yang beredar memberi pengaruh terhadap pengambilan keputusan berinvestasi. Calon investor menggunakan informasi yang telah beredar di pasar modal digunakan untuk mempertimbangkan penyaluran dana. Calon investor dapat mengamati investasi mana yang semakin tinggi dalam menghasilkan laba dan investasi mana yang semakin kecil risikonya. Sedangkan bagi perusahaan yang membutuhkan dana tambahan, informasi yang beredar akan sangat mempengaruhi perbedaan harga saham dari masing-masing sekuritas.

Berdasarkan research gap di atas, rumusan masalah penelitian ini adalah, apakah terdapat perbedaan pada abnormal return dan trading volume activity sebelum dan setelah kesepakatan investasi antara pemerintah Indonesia dengan pemerintah Arab Saudi.

Tujuan penelitian ini adalah untuk meneliti dan menemukan bukti empiris mengenai reaksi pasar modal Indonesia terhadap keputusan investasi Raja Salman di Indonesia.

\section{KAJIAN PUSTAKA Pasar Modal}

Pengertian pasar modal secara umum adalah tempat bertemunya pihak yang kelebihan dana (the lender) dengan pihak yang membutuhkan dana (the borrower). Pasar modal merupakan pasar (tempat berupa gedung) yang digunakan untuk memperdagangkan saham, obligasi dan surat berharga lainnya dengan memakai jasa perantara pedagang efek (Sunariyah, 2011).
Manfaat melakukan investasi di pasar modal sebagai investor (yang membeli sekuritas) adalah untuk memperoleh dividen atau keuntungan ketika mengalirkan dananya kepada perusahaan tertentu yang dianggap dapat berkembang sesuai dengan pertumbuhan ekonomi. Sedangkan manfaat berinvestasi bagi emiten (yang menerbitkan sekuritas) keberadaan pasar modal dipakai sebagai alternatif untuk menghimpun dana eksternal tanpa menggunakan intermediasi keuangan.

\section{Studi Peristiwa (Event Study)}

Studi peristiwa adalah studi yang mempelajari mengenai reaksi pasar terhadap peristiwa yang dipublikasikan sebagai pengumuman dan bisa digunakan untuk menguji kandungan sebuah informasi dari pengumuman tersebut. Tujuan penggunaan metode studi peristiwa adalah untuk menguji kandungan sebuah informasi dari pengumuman. Apabila sebuah pengumuman mengandung informasi, pasar diharapkan akan bereaksi pada waktu pengumuman tersebut diterima (Hartono, 2010).

Jumlah periode pengamatan penelitian sangat bervariasi. Mardiyati dan Khasanah (2011:78) menuliskan bahwa patokan umum yang digunakan berkisar 3 hari sampai 121 hari untuk data harian dan 3 bulan sampai 121 bulan untuk data bulanan. Keputusan investasi Raja Salman di Indonesia bulan Maret 2017 disebutsebut dapat memberikan efek positif terhadap pasar modal Indonesia, terlebih Raja Salman adalah tokoh yang sangat berpengaruh di kawasan Timur Tengah. Keputusan investasi Raja Salman tersebut diyakini memiliki kandungan informasi yang berarti bagi para pelaku pasar, terutama bagi investor yang menjadikan informasi ini sebagai alat pengambilan keputusan dalam berinvestasi.

Kesepahaman tersebut mencakup peningkatan hubungan kedua negara dalam bidang kerja sama luar negeri, kesehatan, kebudayaan, transportasi, aeronautika, 
pendidikan, keagamaan dan perdagangan (ristekdikti.go.id, 11 Juli 2018).

Berikut ini adalah kesepahaman yang berhasil dicapai oleh kedua negara:

1. Deklarasi bersama antara pemerintah Indonesia dengan Arab Saudi perihal peningkatan pimpinan Sidang Komisi Bersama.

2. Kesepahaman kerja sama dalam bidang kebudayaan antara Kementrian Pendidikan dan Kebudayaan Republik Indonesia bersama dengan Kementrian Kebudayaan dan Informasi Arab Saudi.

3. Program kerja sama antara Kementrian Koperasi dan Usaha Kecil dan Menengah Republik Indonesia dengan Otoritas Usaha Kecil dan Menengah Arab Saudi mengenai pengembangan usaha kecil dan menengah.

4. Nota kesepahaman antara Kementrian Kesehatan Republik Indonesia dengan Kementrian Kesehatan Arab Saudi di bidang kesehatan.

5. Nota kesepahaman antara otoritas aeronautika pemerintah Republik Indonesia dengan Arab Saudi.

6. Program kerja sama antara Kementrian Riset, Teknologi dan Pendidikan Tinggi Republik Indonesia dengan Kementrian Pendidikan Arab Saudi dalam bidang kerja sama saintifik dan pendidikan tinggi.

7. Nota kesepahaman antara Kementrian Agama Republik Indonesia dan Kementrian Urusan Islam, Dakwah dengan Bimbingan Arab Saudi di bidang urusan Islam.

8. Nota kesepahaman antara pemerintah Republik Indonesia dengan pemerintah Arab Saudi di bidang kerja sama kelautan dan perikanan.

9. Program kerja sama dalam bidang perdagangan antara Kementrian Perdagangan Republik Indonesia dengan Kementrian Perdagangan dan Investasi Arab Saudi.

10. Perjanjian kerja sama pemberantasan kejahatan antara Kepolisian Negara
Republik Indonesia dan Kementrian Dalam Negeri Arab Saudi.

11. Nota kesepahaman tentang kontribusi pendanaan Arab Saudi terhadap pembiayaan proyek pembangunan antara Saudi Fund for Development dengan Pemerintah Republik Indonesia.

\section{Definisi Return}

Return adalah hasil yang di dapat dari sebuah investasi. Return terbagi menjadi dua, yaitu return realisasi yang sudah terjadi dan return ekspektasi yang artinya belum terjadi namun diharapkan akan terjadi di masa mendatang. Return realisasi dihitung berdasarkan data-data historis. Return historis berguna sebagai dasar penentuan return ekspektasi dan risiko di masa yang akan datang. Berbeda dengan return realisasi yang sifatnya sudah terjadi terlebih dahulu, return ekspektasi sifatnya belum terjadi (Jogiyanto, 2010: 107).

Rumus yang digunakan untuk menghitung return saham menurut Jogiyanto (2010: 416) yaitu:

Di mana:

$$
R T=\frac{P_{T}-P_{T-1}}{P_{T-1}}
$$

$\mathrm{R}_{T} \quad$ : Return saham pada periode ke-t

$P_{T} \quad$ : Harga saham untuk waktu ke-t

$P_{T-1} \quad$ : Harga saham waktu sebelumnya

\section{Definisi Abnormal Return}

Efisiensi pasar diuji dengan melihat abnormal return (return tidak normal). Pasar dapat dikatakan tidak efisien apabila satu atau beberapa pelaku pasar modal menikmati abnormal return dalam jangka waktu yang cukup lama (Jogiyanto, 2010:415).

Apabila return yang diperoleh lebih besar dari return yang diharapkan, berarti abnormal return positif. Ini adalah hal yang sangat diharapkan oleh investor. Sedangkan jika return realisasi lebih kecil dari return ekspetasi, berarti abnormal return negatif. 
Kartika Wijaya \& Hendra Gunawan, Reaksi Pasar Modal Indonesia Terhadap...

Rumus untuk menghitung abnormal return menurut Jogiyanto (2010:416) yaitu:

$$
R T \text { Ni.t }=\text { Ri.t }-E(\text { Ri.t })
$$

Di mana:

\section{RTNi.t : Retun tidak normal (abnormal return) sekuritas ke-I pada periode peristiwa ke- $\mathrm{t}$ \\ Ri.t : Return sesungguhnya yang terjadi untuk saham ke-i pada periode peristiwa ke- $t$ \\ $E[$ Ri.t] : Return ekspetasi saham ke-i untuk periode peristiwa ke-t}

\section{Market Adjusted Model}

Model ini menganggap jika penduga terbaik untuk mengestimasi return suatu sekuritas adalah dengan menggunakan return indeks pasar. Menggunakan model ini, tidak diperlukan lagi memakai periode estimasi untuk membentuk model estimasi karena return sekuritas yang diestimasi sama dengan return pasar.

$$
\text { Arit }=\text { Rit }- \text { Rmt }
$$

Di mana:

Arit : Abnormal return saham i pada hari ke $\mathrm{t}$

Rit : Actual return saham i pada hari ke $\mathrm{t}$

Rmt : Return pasar, dihitung dengan rumus

$$
R m t=\frac{(\text { IHSG }-I H S G k-a)}{I H S G t-1} \text { dengan }
$$

IHSG adalah Indeks Harga Saham Gabungan

\section{Average Abnormal Return}

Average abnormal return adalah selisih antara return yang diharapkan dengan aktual return yang diperoleh. Selisih return akan positif jika return yang diperoleh lebih besar dari return yang diharapkan. Rumus menghitung average abnormal return (Kurnianingsih, 2014):

$$
\text { AAR }{ }_{i t} \frac{\sum_{i=1}^{k} A R i t}{k}
$$

Di mana:

AARit : Rata-rata abnormal return pada hari ke t.

Arit : Abnormal return untuk sekuritas ke i pada hari ke $\mathrm{t}$

K : Jumlah sekuritas

\section{Trading Volume Activity (TVA)}

Investor selalu mempertimbangkan risiko dan tingkat keuntungan yang akan didapatkannya sebelum membuat keputusan investasi. Maka dari itu investor sangat membutuhkan informasi untuk melakukan analisis saham. Adanya informasi yang beredar di pasar akan mengubah pandangan investor dalam mengambil keputusan. Setiap informasi yang beredar akan menimbulkan reaksi pasar. Reaksi pasar inilah yang dapat dilihat dari aktivitas volume perdagangan saham.

Menurut Rachmadani, dkk (2013) untuk menghitung aktivitas volume perdagangan saham digunakan persamaan sebagai berikut:

$\mathrm{TVA}_{i t} \frac{\text { Saham perusahaan } i \text { diperdagangkan waktu } t}{\text { Saham perusahaan } i \text { yang beredar di BEI pada waktu } t}$

\section{Average Trading Volume Activity}

Trading volume activity yang telah diketahui maka langkah selanjutnya adalah mengukur rata-rata atau average trading volume activity dengan menggunakan persamaan sebagai berikut:

$$
X T V A, t=\frac{\sum T V A, t}{n}
$$

Di mana:

XTVA,t : Rata-rata trading volume activity perusahaan i pada waktu ke - $t$

$\sum$ TVA,t: Jumlah trading volume activity

$\mathrm{N}$ : Jumlah perusahaan

Berikut adalah beberapa penelitian yang telah menggunakan event study, antara 
lain adalah Nailiu (2014) dan Silfina, \& Gunawan, (2019). Penelitian Nailiu (2014) menggunakan data perusahaan yang tergabung dalam indeks LQ 45 pada periode Februari sampai Juli 2014 sebagai sampel. Hasil dari penelitian Nailiu (2014) pasar modal Indonesia bereaksi negatif terhadap peristiwa pengumuman pencalonan Joko Widodo. Penelitian lain yang dilakukan oleh Pratama, Sinarti dan Dharmawan (2015) membuktikan bahwa peristiwa pelantikan Joko Widodo sebagai presiden republik Indonesia menunjukkan pasar memberi respon positif signifikan.

Penelitian luar negeri seperti ChunHung (2011) mendapati hasil penelitiannya menunjukkan pasar saham Taiwan sensitif terhadap pemilihan presiden di Amerika Serikat. Peristiwa bencana alam badai salju di Cina pada tahun 2011 juga menunjukkan adanya reaksi pasar modal di Shenzhen Stock Exchange di Cina (Cao, Xu \& Guo, 2015). Hasil penelitiannya menunjukkan bahwa badai salju memberikan abnormal return yang positif terhadap perusahaanperusahaan yang bergerak di bidang industri konstruksi, tekstil, dan pakaian. Sementara itu di lain sisi bencana alam badai salju juga memberikan abnormal return yang negatif terhadap perusahaan yang bergerak di bidang permesinan dan industri media. Selain itu terdapat juga beberapa penelitian mengenai kinerja pasar modal seperti Yulandari \& Gunawan (2019) dan Chen. (2005).

Berdasarkan penelitian yang telah diuraikan di atas, maka penelitian ini dimaksudkan sebagai pengembangan dari berbagai event study yang telah dilakukan sebelumnya dengan menganalisis reaksi pasar terhadap peristiwa yang terjadi di dalam negeri.

\section{METODE}

\section{Desain/Jenis Penelitian}

Jenis penelitian yang digunakan dalam penelitian ini adalah studi peristiwa (event study).

\section{Objek dan Ruang Lingkup Penelitian}

Objek penelitian ini merupakan seluruh perusahaan yang sahamnya terdaftar di Bursa Efek Indonesia (BEI) tahun 2017. Perusahaan yang menjadi populasi pada penelitian ini berjumlah 539 perusahaan (data diambil dari tanggal 01 Februari 2017 hingga 29 Maret 2017 pada situs www.idx.co.id).

Variabel independen penelitian ini merupakan event kesepakatan investasi antara pemerintah Indonesia dengan pemerintah Arab Saudi. Data lalu dikelompokkan menjadi data sebelum event dan data setelah event. Terdapat dua variabel dependen dalam penelitian ini, yakni aktual abnormal return harian saham dan volume trading activity harian. Variabel ini diamati selama dua bulan, yakni sebulan sebelum, satu hari peristiwa dan sebulan setelah keputusan investasi Raja Salman di Indonesia.

\section{Operasionalisasi Variabel Penelitian}

Variabel independen dalam penelitian ini adalah peristiwa keputusan investasi Raja Salman di Indonesia pada tanggal 01 Maret 2017. Data selanjutnya dianalisis dengan cara membandingkan nilai abnormal return dan trading volume activity sebelum dan setelah event, yakni sebulan sebelum tanggal 01 Maret 2017 dan sebulan setelah tanggal 01 Maret 2017.

Variabel dependen dalam penelitian ini adalah aktual return harian saham dan volume penjualan harian saham. Data yang digunakan adalah harga penutupan saham harian dan total perdagangan saham harian.

Abnormal return digunakan untuk mencermati apakah informasi keputusan investasi yang dilakukan oleh Raja Salman di Indonesia akan mempengaruhi return saham negatif atau positif pada periode pengamatan. Sementara trading volume activity digunakan untuk mencermati volume perdagangan saham, dalam artian apakah informasi keputusan investasi Raja 
Kartika Wijaya \& Hendra Gunawan, Reaksi Pasar Modal Indonesia Terhadap...

Salman di Indonesia mempengaruhi net buy dan net sell investor.

\section{Populasi dan Sampel}

Populasi dan sampel yang digunakan dalam penelitian ini merupakan seluruh perusahaan yang terdaftar di Bursa Efek Indonesia (BEI), yaitu 539 perusahaan (data diambil dari tanggal 01 Februari 2017 hingga 29 Maret 2017 pada situs www.idx.co.id.

Tabel 1. Proporsi Sektor Perusahaan

\begin{tabular}{|l|l|r|}
\hline No & \multicolumn{1}{|c|}{ Sektor Perusahaan di BEI } & Jumlah \\
\hline 1 & Sektor Pertanian & 21 \\
\hline 2 & Sektor Pertambangan & 42 \\
\hline 3 & Sektor Industri Dasar dan Kimia & 67 \\
\hline 4 & Sektor Aneka Industri & 43 \\
\hline 5 & Sektor Industri Barang Konsumsi & 38 \\
\hline 6 & $\begin{array}{l}\text { Sektor Properti, Real Estate dan Konstruksi } \\
\text { Bangunan }\end{array}$ & 58 \\
\hline 7 & Sektor Infrastruktur, Utilitas dan Transportasi & 56 \\
\hline 8 & Sektor Keuangan & 92 \\
\hline 9 & Sektor Perdagangan Jasa dan Investasi & 122 \\
\hline & TOTAL SAMPEL & 539 \\
\hline
\end{tabular}

Sumber: $w w w . i d x . c o . i d$

\section{Jenis dan Sumber Data}

Jenis data penelitian ini adalah data kuantitatif berupa perdagangan saham harian di Bursa Efek Indonesia (BEI). Pengambilan data berdasarkan waktu dan ketentuan yang telah ditetapkan oleh peneliti. Sumber data yang digunakan merupakan data sekunder yang bersumber dari data historis BEI. Sumber utama data diperoleh dari situs resmi Bursa Efek Indonesia (www.idx.com) dan Yahoo finance sebagai referensi tambahan.

\section{Teknik Pengumpulan Data}

Data yang digunakan merupakan data sekunder sehingga prosedur pengumpulan data menggunakan teknik dokumentasi dengan cara melakukan pencatatan dan pentabulasian untuk diolah sesuai dengan kebutuhan. Data diperoleh dari situs Bursa Efek Indonesia, Yahoo Finance ataupun situs-situs lain yang menginformasikan data perusahaan yang dibutuhkan peneliti.

Jenis data penelitian ini adalah data dengan skala pengukuran rasio. Data penelitian ini merupakan harga penutupan saham perusahaan harian untuk mencari return saham dan volume perdagangan saham harian selama periode peristiwa berlangsung.

\section{Statistik Deskriptif}

Teknik analisis data pada penelitian kuantitatif adalah dengan menggunakan statistik. Analisis data penelitian ini merupakan statistik deskriptif. Pengukuran yang digunakan dalam penelitian ini adalah mean, median, standar deviasi, nilai minimum, dan nilai maksimum. Analisis tersebut bertujuan untuk memberikan gambaran mengenai perilaku dan distribusi data.

\section{Uji Normalitas Data}

Uji Normalitas pada penelitian ini tidak dilakukan karena berdasarkan Ghasemi dan Zahediasl (2012: 486-489) data yang banyaknya > 30 atau 40 dapat diasumsikan telah berdistribusi normal. Penelitian ini menggunakan sampel dalam jumlah besar karena sampel yang diambil merupakan semua data yang menjadi populasi.

\section{HASIL DAN PEMBAHASAN}

Pengujian hipotesis dilakukan dengan menggunakan uji parsial atau uji t. Uji t dilakukan dengan menggunakan paired simple t-test. Pengujian ini dilakukan untuk mengetahui apakah terdapat perbedaan ratarata dua sampel berpasangan atau yang terkait. Data yang menjadi objek dalam penelitian ini merupakan abnormal return dan trading volume activity 19 hari sebelum dan 19 hari setelah kesepakatan investasi yang dilakukan antara pemerintah Indonesia dengan pemerintah Arab Saudi.

Dasar pengambilan keputusan dalam uji t untuk analisis regresi ini berdasarkan nilai signifikansi hasil keluaran SPSS apabila nilai probabilitas Sig. (2-tailed) $<0.05$ maka terdapat perbedaan signifikan antara nilai sebelum dan setelah kesepakatan investasi antara pemerintah Indonesia dengan pemerintah Arab Saudi. Lalu apabila nilai Sig. (2-tailed) >0.05 maka tidak terdapat perbedaan signifikan 
antara abnormal return dan trading volume activity sebelum dan setelah kesepakatan investasi antara pemerintah Indonesia dengan pemerintah Arab Saudi. Uji hipotesis penelitian ini dilakukan untuk menguji abnormal return dan trading volume activity sebelum dan setelah peristiwa pada seluruh sampel secara simultan (539 perusahaan).

\section{Uji Paired Sample t-test Abnormal Return Keseluruhan Sampel Secara Bersamaan}

Berdasarkan perbandingan yang di lihat dari nilai probabilitas Sig. (2 tailed), terdapat perbedaan rata-rata abnormal return sebelum dan setelah kesepakatan investasi pada periode pengamatan hari ke 12, 11, 09 dan 01. Sementara periode pengamatan pada hari lainnya nilai Sig. > 0.05 yang berarti tolak $\mathrm{H}_{1}$. Dikatakan dengan tingkat signifikansi $5 \%$ didapatkan kesimpulan rata-rata abnormal return sebelum dan setelah kesepakatan investasi adalah sama atau tidak terdapat perbedaan secara nyata. Dinyatakan bahwa peristiwa kesepakatan investasi antara pemerintah Indonesia dengan pemerintah Arab Saudi tidak mempengaruhi abnormal return keseluruhan saham-saham BEI untuk tingkat signifikansi 5\%. Sehingga hipotesis yang menyatakan bahwa terdapat perbedaan abnormal return keseluruhan saham BEI antara sebelum dan setelah event kesepakatan investasi tidak terbukti kebenarannya atau $\mathrm{H}_{1}$ ditolak.

Tabel 2. Uji Paired Sample t-test Abnormal Return

\begin{tabular}{|c|c|c|c|}
\hline \multirow{2}{*}{ Pair } & \multicolumn{3}{|c|}{ Paired Samples Test } \\
\cline { 2 - 4 } & $\mathbf{T}$ & df & Sig. (2-tailed) \\
\hline Arit -19 dan +19 & -0.501 & 538 & $0.616^{* *}$ \\
\hline Arit -18 dan +18 & -0.603 & 538 & $0.547^{* *}$ \\
\hline Arit -17 dan +17 & 1.48 & 538 & $0.139^{* *}$ \\
\hline Arit -16 dan +16 & -1.047 & 538 & $0.296^{* *}$ \\
\hline Arit -15 dan +15 & -0.879 & 538 & $0.38^{* *}$ \\
\hline Arit -14 dan +14 & -0.184 & 538 & $0.854^{* *}$ \\
\hline Arit -13 dan +13 & -0.496 & 538 & $0.62^{* *}$ \\
\hline Arit -12 dan +12 & 2.55 & 538 & $0.011^{* *}$ \\
\hline Arit -11 dan +11 & 3.835 & 538 & $.000^{* *}$ \\
\hline Arit -10 dan +10 & -0.997 & 538 & $0.319^{* *}$ \\
\hline Arit -09 dan +09 & -2.791 & 538 & $0.005^{* *}$ \\
\hline Arit -08 dan +08 & 0.701 & 538 & $0.483^{* *}$ \\
\hline Arit -07 dan +07 & 0.829 & 538 & $0.408^{* *}$ \\
\hline
\end{tabular}

\begin{tabular}{|c|c|c|c|}
\hline Arit -06 dan +06 & -0.646 & 538 & $0.518 * *$ \\
\hline Arit -05 dan +05 & -1.222 & 538 & $0.222 * *$ \\
\hline Arit -04 dan +04 & -1.592 & 538 & $0.112 * *$ \\
\hline Arit -03 dan +03 & 1.245 & 538 & $0.214 * *$ \\
\hline Arit -02 dan +02 & -0.233 & 538 & $0.816 * *$ \\
\hline Arit -01 dan +01 & 4.001 & 538 & $.000 * *$ \\
\hline \multicolumn{4}{|c|}{$\begin{array}{l}\text { Keterangan: Tabel ini merupakan hasil statistik deskriptif variabe } \\
\text { dependen yaitu Abnormal Return (Arit). Abnormal return sebelum event }( \\
\text { ), abnormal return setelah event (+). Angka menunjukkan periode } \\
\text { pengamatan 1-19 hari. }\end{array}$} \\
\hline \multicolumn{4}{|c|}{$\begin{array}{l}* * * \text { Signifikansi level } 1 \%, * * \text { Signifikansi level } 5 \% \text {, dan } * \text { Signifikansi } \\
\text { level } 10 \%\end{array}$} \\
\hline
\end{tabular}

Uji Paired Sample t-test Trading Volume Activity Keseluruhan Sampel Secara Bersamaan

Berdasarkan dari perbandingan nilai probabilitas Sig. (2 tailed) terlihat bahwa terdapat perbedaan rata-rata trading volume activity sebelum dan setelah kesepakatan investasi pada periode pengamatan hari ke 19, 18 dan 12. Sementara periode pengamatan pada hari lainnya nilai Sig. $>0.05$ yang berarti tolak $\mathrm{H}_{2}$. Dikatakan dengan tingkat signifikansi $5 \%$ didapatkan kesimpulan rata-rata trading volume activity sebelum dan setelah kesepakatan investasi adalah sama atau tidak terdapat perbedaan secara nyata. Dinyatakan bahwa peristiwa kesepakatan investasi antara pemerintah Indonesia dengan pemerintah Arab Saudi tidak mempengaruhi trading volume activity keseluruhan saham-saham BEI untuk tingkat signifikansi $5 \%$. Sehingga hipotesis yang menyatakan bahwa terdapat perbedaan trading volume activity keseluruhan saham BEI antara sebelum dan setelah event kesepakatan investasi tidak terbukti kebenarannya atau $\mathrm{H}_{2}$ ditolak.

Tabel 3. Uji Paired Sample t-test Trading Volume Activity

\begin{tabular}{|c|c|c|c|}
\hline \multirow{2}{*}{ Pair } & \multicolumn{3}{|c|}{ Paired Samples Test } \\
\cline { 2 - 4 } & $\mathbf{T}$ & $\mathbf{d f}$ & Sig. (2-tailed) \\
\hline Arit -19 dan +19 & 2.159 & 538 & $0.031^{* *}$ \\
\hline Arit -18 dan +18 & 2.381 & 538 & $0.018^{* *}$ \\
\hline Arit -17 dan +17 & 1.392 & 538 & $0.165^{* *}$ \\
\hline Arit -16 dan +16 & 1.898 & 538 & $0.058^{* *}$ \\
\hline Arit -15 dan +15 & -0.154 & 538 & $0.878^{* *}$ \\
\hline Arit -14 dan +14 & 0.872 & 538 & $0.384^{* *}$ \\
\hline Arit -13 dan +13 & -0.089 & 538 & $0.929^{*}$ \\
\hline Arit -12 dan +12 & 2.451 & 538 & $0.015^{* *}$ \\
\hline Arit -11 dan +11 & 0.984 & 538 & $0.325^{* *}$ \\
\hline Arit -10 dan +10 & 0.551 & 538 & $0.582^{* *}$ \\
\hline Arit -09 dan +09 & 0.275 & 538 & $0.784^{* *}$ \\
\hline Arit -08 dan +08 & 0.695 & 538 & $0.488^{* *}$ \\
\hline
\end{tabular}


Kartika Wijaya \& Hendra Gunawan, Reaksi Pasar Modal Indonesia Terhadap...

\begin{tabular}{|c|c|c|c|}
\hline Arit -07 dan +07 & 0.561 & 538 & $0.575 * *$ \\
\hline Arit -06 dan +06 & 0.662 & 538 & $0.508 * *$ \\
\hline Arit -05 dan +05 & 0.693 & 538 & $0.488 * *$ \\
\hline Arit -04 dan +04 & 0.213 & 538 & $0.831 * *$ \\
\hline Arit -03 dan +03 & 0.719 & 538 & $0.472 * *$ \\
\hline Arit -02 dan +02 & 0.821 & 538 & $0.412 * *$ \\
\hline Arit -01 dan +01 & 0.852 & 538 & $0.394 * *$ \\
\hline \multicolumn{4}{|c|}{$\begin{array}{l}\text { Keterangan: Tabel ini merupakan hasil statistik deskriptif variabe } \\
\text { dependen yaitu Trading Volume Activity (TVA). Trading volume activity } \\
\text { sebelum event (-), Trading volume activity setelah event (+). Angk } \\
\text { menunjukkan periode pengamatan } 1-19 \text { hari. }\end{array}$} \\
\hline \multicolumn{4}{|c|}{$\begin{array}{l}* * * \text { Signifikansi level } 1 \%, * * \text { Signifikansi level } 5 \% \text {, dan * Signifikansi } \\
\text { level } 10 \%\end{array}$} \\
\hline
\end{tabular}

\section{SIMPULAN DAN SARAN}

Hasil Abnormal return menunjukkan bahwa tidak terdapat perbedaan yang signifikan dalam peristiwa kesepakatan investasi antara pemerintah Indonesia dengan pemerintah Arab Saudi. Informasi yang terkandung dalam peristiwa tersebut tidak besar atau tidak kuat, sehingga tidak secara signifikan terlihat perbedaan rataratanya terhadap abnormal return. Hal ini berarti pasar tidak bereaksi atas peristiwa tersebut yang ditunjukkan dengan tidak adanya perubahan harga saham yang menyebabkan terjadinya abnormal return positif dari kondisi sebelum dan setelah event.

Perbedaan abnormal return saham tidak signifikan atas peristiwa kesepakatan investasi antara pemerintah Indonesia dengan pemerintah Arab Saudi adalah persepsi yang berbeda dari masing-masing investor sesuai dengan informasi yang didapat. Pasar modal tidak banyak berekspektasi tinggi atas kunjungan Raja Salman ke Indonesia. Sebelumnya, Raja Salman diharapkan akan berinvestasi di saham infrastruktur Indonesia tetapi ternyata tidak.

Hasil trading volume activity menunjukkan tidak adanya perbedaan yang signifikan dalam peristiwa kesepakatan investasi antara pemerintah Indonesia dengan pemerintah Arab Saudi. Peristiwa kesepakatan investasi tersebut tidak mempengaruhi keputusan investor dalam melakukan aksi buy dan sell yang di aproksikan dalam trading volume activity. Salah satu penyebabnya adalah abnormal return yang terjadi adalah unrealized abnormal return atau abnormal return yang belum terealisasi. Abnormal return yang terealisasi terjadi jika investor menjual sahamnya sehingga return sesungguhnya terjadi. Sementara pada hasil penelitian menunjukkan kemungkinan pelaku pasar cenderung untuk bersikap wait and see atas kesepakatan investasi dan menunggu sampai terealisasinya 11 nota kesepakatan tersebut.

Penyebab lainnya adalah bahwa pada periode pengamatan hari ke 1 dan ke 2 setelah event terjadi abnormal return yang negatif, di mana hal ini memicu investor lebih memilih untuk menjual sahamnya agar menghindari risiko.

\section{Saran}

Berdasarkan kesimpulan yang telah dijabarkan, peneliti memberi beberapa saran yang mungkin dapat digunakan sebagai pertimbangan dalam penelitian selanjutnya. Adapun saran yang diberikan adalah sebagai berikut:

1. Penelitian selanjutnya diharapkan untuk melakukan uji pengaruh sehingga dapat diketahui presentase pengaruh politik, khususnya kesepakatan kerjasama antara pemerintah Indonesia dan pemerintah Arab Saudi terhadap perubahan abnormal return dan trading volume activity pada saham-saham BEI.

2. Penelitian selanjutnya sebaiknya tetap memakai jumlah sampel penelitian dengan menggunakan seluruh populasi saham BEI dengan event window yang lebih lama, misalnya 100 hari sebelum dan 100 hari setelah event.

3. Penelitian selanjutnya diharapkan untuk melakukan pengujian hipotesis menjadi 2 tahap, yakni tahap pertama melakukan pengujian abnormal return dan trading volume activity sebelum dan setelah event pada keseluruhan saham BEI secara bersamaan lalu tahap kedua melakukan pengujian yang dibagi ke dalam 9 sektor BEI.

4. Penelitian selanjutnya diharapkan untuk menambah variabel kontrol, misalnya perubahan kurs mata uang dalam 
menguji pengaruh peristiwa politik khususnya kerjasama negara antar pemerintah Indonesia dan pemerintah Arab Saudi.

\section{DAFTAR PUSTAKA}

Alam, A. (2013). Terrorism and stock market development: causality evidence from Pakistan. Journal of Financial Crime, 20(1), 116-128.

Asghar Ghasemi, S. Z. (2012). Normality Tests for Statistical Analysis: A Guide for Non-Statisticians. Endocrinology \& Metabolism, 486-489.

Cao, G., Xu, W., \& Guo, Y. (2015). Effects of climatic events on the Chinese stock market: applying event analysis. Natural Hazards, 77(3), 1979-1992.

Chen. (2005). An Empirical Investigation of The Relationship Between Intellectual Capital and Firms' Market Value and Financial Performance. Journal Intellectual Capital, 159-176.

Chun-Hung, L. (2011). The Presidential Elections and the Stock Market in Taiwan. Issue and Studies, 49 (1).

Damarjati, D. (2017, Maret 01). Ini 11 MoU antara Indonesia dan Arab Saudi. Retrieved Februari 04, 2018, from www.news.detik.com: https://news.detik.com/berita/d3435465/ini-11-mou-antara-indonesiadan-arab-saudi

Firmansyah, A. D. (2016, Mei). Analisis Perbandingan Trading Volume Activity Dan Abnormal Return Sebelum Sesudah Stock Split. Jurnal Ilmu dan Riset Manajemen, V(5).

Ghozali, I. (2012). Aplikasi Analisis Multivariate dengan Program IBM SPSS. Semarang: UNDIP.

Gujarati, D. N. (2012). Dasar-dasar Ekonometrika, Terjemahan Mangunsong, R.C. (Edisi 5 ed., Vol. Buku 2). Jakarta: Salemba Empat.

Hartono, J. (2010). Studi Peristiwa: Menguji Reaksi Pasar Modal Akibat
Suatu Peristiwa. Yogyakarta: BPFE Yogyakarta.

Hartono, J. (2014). Teori Portofolio dan Analisis Investasi (Edisi 8 ed.). Yogyakarta: BPFE.

Hidayat, R. (2017, Maret 01). Disepakati kerja sama Arab Saudi-Indonesia senilai Rp93 triliun. Retrieved Februari 04, 2018, from www.bbc.com: http://www.bbc.com/indonesia/indones ia-39130419

Irham, F. (2012). Pengantar Pasar Modal (Edisi Pertama ed.). Bandung: Alfabeta.

Jogiyanto. (2010). Menguji Reaksi Pasar Modal akibat Suatu Peristiwa (1st ed.). Yogyakarta: BPFE.

Jogiyanto, H. (2013). Teori Portofolio dan Analisis Investasi (8 ed.). Yogyakarta: BPFE.

Kurnianingsih, H. (2014). Analisis Reaksi Pasar Terhadap Pengumuman Dividen. Surakarta: Universitas Sebelas Maret.

Kuwado, F. J. (2017, Maret 01). Ini Kegiatan Hari Pertama Raja Salman di Indonesia. Retrieved Februari 04, 2018, from www.nasional.kompas.com: https://nasional.kompas.com/read/2017 /03/01/06502361/ini.kegiatan.hari.perta ma.raja.salman.di.indonesia

Lestari, M. A. (2016). Reaksi Pasar Modal Indonesia Terhadap Terpilihnya Donald Trump. 64.

Luhur, S. (2010). Reaksi Pasar Modal Indonesia Seputar Pemilihan Umum 8 Juli 2009 pada Saham LQ-45. Jurnal Keuangan dan Perbankan, 14(2).

Machmudin, B. (2017, Maret 01). Ini 11 Nota Kesepahaman Indonesia-Arab Saudi saat Kunjungan Raja Salman. Retrieved Juli 11, 2018, from www.ristekdikti.go.id: https://www.ristekdikti.go.id/ini-11nota-kesepahaman-indonesia-arabsaudi-saat-kunjungan-raja-salman/

Mardiyati, U., \& Khasanah, K. (2011). Studi Komparatif Harga, Likuiditas, 
Kartika Wijaya \& Hendra Gunawan, Reaksi Pasar Modal Indonesia Terhadap...

dan Resiko Saham Sebelum dan Sesudah Perusahaan Melakukan Stock Split dan Reserve Split di Bursa Efek Indonesia Tahun 2004-2009. Jurnal Riset Manajemen Sains Indonesia (JRMSI), 2.

Nailiu, B. (2014). Pengaruh Pengumuman Pencapresan Jokowi 2014 di Bursa Efek Indonesia. Jokowi Effect pada Saham LQ45.

Pratama, I. B., Sinarwati, N. K., \& Darmawan, N. A. (2015). Reaksi Pasar Modal Indonesia Terhadap Peristiwa Politik (Event Study pada Peristiwa Pelantikan Joko Widodo Sebagai Presiden Republik Indonesia Ke-7). $e$ Journal S1 Ak Universitas Pendidikan Ganesha, 3(1).

Sanjay Kumar, J. L. (2013). Impact of Terrorism on Internatioal Stock Market. Journal of Applied Business and Economics, 14,Iss.4,pp.42-60.

Silfina, S., \& Gunawan, H. (2019). Pengaruh Manajemen Modal Kerja dan Solvabilitas terhadap Kinerja Perusahaan. Jurnal Akuntansi, Ekonomi dan Manajemen Bisnis| $e$ ISSN: 2548-9836, 7(1), 94-104.

Sugiyono. (2010). Metode Penelitian Pendidikan. Bandung: Alfabeta.

Sugiyono. (2012). Metode Penelitian Bisnis. Bandung: Alfabeta.
Sunariyah. (2011). Pengantar Pengetahuan Pasar Modal (Keenam ed.). Yogyakarta: UPP STIM YKPN.

Vibby, S. (2010). Jual Saham Anda Lebih Mahal (Edisi Kedua ed.). Jakarta: Vibby Publishing.

Yulandari, L., \& Gunawan, H. (2019). Pengaruh Intellectual Capital terhadap Nilai Pasar dan Kinerja Keuangan Perusahaan yang Terdaftar di Bursa Efek Indonesia. Journal of Applied Managerial Accounting, 3(1), 36-50.

Yulita, I. K. (2017). Reaksi Pasar Modal Terhadap Pengumuman Keputusan Investasi Raja Salman Di Indonesia.

Ziobrowski A., B. J. (2011). Abnormal Returns from The Common Stock Investments of Members of The U.S. House of Representatives Stock Market. Journal Business and Politic, 13(4).

Zuraya, N. (2017, Maret 01). Dampak Kedatangan Raja Salman Terhadap Pasar Keuangan Indonesia. Retrieved April 21, 2018, from www.repbulika.co.id:

http://republika.co.id/berita/ekonomi/k euangan/17/03/01/om495i383-dampakkedatangan-raja-salman-terhadappasar-keuangan-indonesia. 